\title{
VERSE STRUCTURE AND MUSICAL RHYTHM IN LATIN HYMN MELODIES*
}

Fred BÜTTNER

\begin{abstract}
As Thrasybulos Georgiades in his book Music and Language has demonstrated, the "problem of the constant preoccupation of music with language" represents one of the major factors of European Music History. In order to deal with this problem adequately it is, above all, the question about rhythm on the language and on the musical level that has to be asked. In the Latin Hymn, the oldest song genre of European Music History, rhythm materializes on the language level in the structure of verses which has originally resulted from adding long and short syllables in some predefined constellation. Since the distribution of word accents, however, may differ considerably from this constellation, musical rhythm (if adopted at all) has the choice to what extent verse structure or divergent word accents should be regarded. Taking Spanish Hymn melodies as examples, it becomes evident what consequences for the rhythmic behaviour of music arise from these possibilities and what perspectives they include for the development of European Music History.
\end{abstract}

\section{Resumen}

Como ha demostrado Thrasybulos Georgiades en su libro Music and Language, la "cuestión de la constante preocupación de la música por el lenguaje" representa uno de los elementos más importantes en la historia de la Música en Occidente. Para poder abordar adecuadamente el problema, es necesario, por encima de todo, plantearse la cuestión del ritmo en los planos lingüístico y musical. En el Himno latino, el género más antiguo de canción en la historia de la Música Occidental, el ritmo se materializa en el plano lingüístico a través de la estructura de los versos, que se construyen originalmente por yuxtaposición de sílabas largas y cortas en una estructura predefinida. Dado que la distribución de los acentos del texto puede apartarse considerablemente de esta estructura, el ritmo musical -si es que éste existe- debe elegir entre seguir la estructura de los versos o la de los acentos del texto. Si tomamos como ejemplos las melodías españolas de los Himnos, resultan evidentes las consecuencias que para el ritmo de la música suponen estas posibilidades, y las perspectivas que se abren para el desarrollo de la historia de la Música en Occidente.

When about fifty years ago Thrasybulos Georgiades, the Greek-born musicologist who found a second home in Germany, set about explaining in a relatively small volume to a wider public the "Rise of Western Music", its birth and change throughout the course of centuries, he chose, as he saw it, an aspect of crucial importance in interpreting Music History as a process which embodies some inner meaning by putting his considerations under the heading of Music and Language ${ }^{1}$. In the words of the

* The present article was given first as a lecture at the Tokyo Geij'utsu Daigaku, Japan, on 17th October 2003. I am very grateful to Inge B. Milfull and Denis Goddard who have made the necessary emendations to convert my "Bavarian English" into real English. Furthermore, I would like to thank Gabriel Mainer Albiac for his Spanish translation of the "Abstract".

1. The text is available in an English translation by one of Georgiades' pupils, Marie Louise Göllner: Thrasybulos 
author, taken from the "Introduction", the book aims at representing "the formation of Western music as the problem of the constant preoccupation of music with language"2. Pursuing this object, Georgiades takes, in a methodically well-considered move, as a starting point with regard to language a text which has occupied musicians in Europe again and again from the early Middle Ages up to the $20^{\text {th }}$ century and which in this way establishes a constant factor that extends, essentially unchanged, through the whole of Music History: the text of the Mass or, more strictly speaking, the text of the socalled "Ordinarium missae" - i.e. the five important text sections which normally appear in every Mass celebration (Kyrie, Gloria, Credo, Sanctus and Agnus dei).

If we are willing to agree to the premise maintained by Georgiades that "the constant preoccupation of music with language" was decisive in the formation and growth of occidental music, it seems worthwhile to follow the approach carried out by him in Music and Language. With this in mind, the present article aims exactly at that purpose: taking seriously the "preoccupation of music with language" in Western civilization and studying the relation between music and language on the basis of concrete examples ${ }^{3}$. But we will direct our attention, instead of the "Ordinarium missae", towards another kind of texts which nevertheless, like the "Ordinarium missae", is present in the history of Western music from the very beginning and which was also treated musically up to the $20^{\text {th }}$ century.

Not by chance it is once again a genre which belongs to the Service of the Catholic church since it is from here that the development not only of Western music, but of Western culture as a whole starts, though with incessant reference to the Greek and Roman heritage, "pagan" according to Christian understanding. I am talking about the "hymn", Latin songs which can be traced back as far as late antiquity, in other words, to the times of early Christianity, and for the present article we will choose chiefly among the vast repertory of hymns a specific type that actually constitutes the historical backbone of this genre, the so-called "Ambrosian hymn", named after St. Ambrose, bishop of Milan in the $2^{\text {nd }}$ half of the $4^{\text {th }}$ century. This "Ambrosian" form of the hymn consists, like the other hymn forms, of several stanzas which, in the "Ambrosian" form, have four verses each, and every verse is built according to a fixed metrical model, the so-called "iambic dimeter".

In brief, the "iambic dimeter" is a verse form made of eight syllables, usually in the pattern short syllable - long syllable. To understand this, we must keep in mind that the syllables of ancient Greek and Latin poetry, in compliance with certain rules, were measured as long or short, with the long syllable having double length compared with the short syllable. This means that each line of verse already provides for its recitation, including its musical recitation, within a rhythmic framework, even if -as should be added in qualification- there are positions in the verse where a short syllable may be replaced

Georgiades, Music and Language: The Rise of Western Music as Exemplified in Settings of the Mass (Cambridge / London / New York etc. 1982).

2. Göllner, p. 2f., renders the German word "Auseinandersetzung" in English as "confrontation". Without having the intention of calling into doubt this possibility I would prefer, for the purpose of our own reflections, the English word "preoccupation" to make it more obvious that we are talking about a very serious spiritual task music undertakes in the process of Music History, with a total metamorphosis of music itself as a result.

3. I think it goes without saying that the question of the relation between music and language can be applied to other cultures as well and that the findings thereby gained may be significant for a better understanding of those cultures, as on the other hand they may have a retroactive effect on our view of occidental music. 
by a long one. But to begin with, let us have a look at the metrical model observed by the so-called "Ambrosianus":

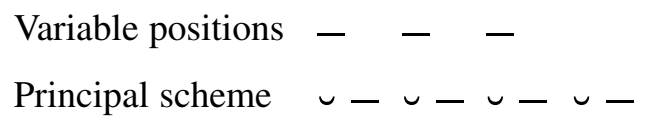

In order to illustrate what we have said about the "iambic dimeter", it will certainly be helpful if we turn to a concrete example now. The example I have chosen is a very famous hymn text used at the beginning of the church year, in the Vesper service of the Advent season, "Conditor alme siderum". The first stanza of this hymn text runs as follows:

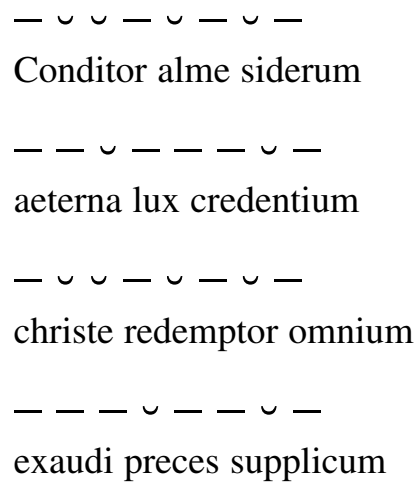

As you may note, there are syllables in this stanza (and the same goes for the remaining stanzas) that do not coincide with the verse form of the "iambic dimeter" or, in other words, syllables that seem to have lost the quantity you would expect them to bear. So the first word already should have a length in its second syllable to fulfill the needs of the "iambic dimeter", but as we can learn from other cases in which this word appears in ancient poetry its second syllable had been always regarded as short: "Cōnd ŭtŏr" and not "Cōndītŏr". The same situation is presented by the first word of verse 3 whose vocative implies a short ending on the second syllable whereas the "iambic dimeter" asks for a long syllable. Finally the second word of verse 4, from time immemorial, starts with a short syllable, though the "iambic dimeter" here requires a long syllable.

Such irregularities point to a relatively late period of origin (centuries after the end of classical antiquity and the beginning of the Middle Ages), and we may ask for the reasons by which they are caused: Had feeling for the traditional quantities in a Latin word been lost and the knowledge of certain rules for defining such quantities forgotten, and was it for this reason that the necessity of harmonizing the long and short syllables with the inner structure of the verse was not seen anymore? Well, 
these are questions which would lead us, above all, to problems connected with the rise of modern European languages and their own poetry, and I would prefer not to go deeper into these problems now. Nevertheless, we will come back to them in the course of our reflections about hymn texts and their musical recitation in later epochs of Music History.

But what about the musical recitation of our hymn text, then? The occurrence of a few wrong quantities does not seem grave enough to affect the verse structure itself, and as I said before, it is the verse structure that already provides for recitation of the verse, including its musical recitation, within a rhythmic framework. So the important fact is that our hymn text cannot be interpreted otherwise than in terms of the so-called "Ambrosianus": This is made sufficiently clear not only by the form of its stanzas consisting of four verses which, in their turn, contain eight syllables, but also by the almost uninterrupted presence of iambic impulses, be it on the metrical level of quantities (long and short syllables), be it on the so-called "rhythmic" level of qualities (strong and weak syllables, i.e. syllables with an accent and syllables without) - another interesting feature, since it is the only possibility left in modern European languages of evaluating a syllable after having abandoned quantities. Taking seriously these results, the obvious thing to do seems to recite this hymn text, and to recite it also musically, in a continuous alternation of short and long positions, in the following way:

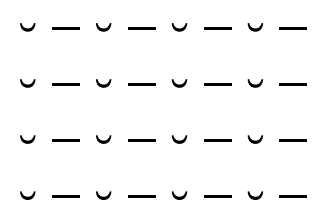

Here, however, we are faced with a problem. Even if it seems probable to us that an Ambrosian hymn text was musically performed like this, we cannot provide evidence to sustain this assumption at least for many centuries. It is not until the $13^{\text {th }}$ century that Western music disposes of a rhythmic notation, and even then the cases in which a hymn melody is notated with the help of these rhythmic signs are rare. Normally hymn melodies are written down in the non-rhythmic plainsong notation which is used for all liturgical chants of the Catholic church. In this notation the most widespread melody for our hymn text "Conditor alme siderum" looks as shown in Example 1 (the source is from Kremsmünster and goes back to the $15^{\text {th }}$ century $)^{4}$.

4. That the manuscript was written at the instigation of Abbot Ulrich IV Schoppenzaun of Kremsmünster in 1464, can be concluded from a contemporary entry on $\mathrm{f}$. $8^{\mathrm{v}}$. In the following year 1465 the manuscript served as model for a second copy (Kremsmünster, Stiftsbibliothek, 359) in which the corresponding entry does not appear on f. $8^{\mathrm{v}}$, however, but only at the end. This copy has the melody for "Conditor alme siderum" on $\mathrm{f} .185^{\mathrm{v}}$. - Both notations make use of a four-lines staff, as is the norm in Gregorian chant, and begin with an $f$-clef on the third line from below, which the copy maintains right to the end while the earlier manuscript, with the transition to the second staff at the word "lux", changes to a $c^{l}$-clef on the fourth line. For reasons of clarity Example 1 keeps to the $c^{l}$-clef throughout the entire hymn. 


\section{Example 1 \\ "Conditor alme siderum" \\ Kremsmünster, Stiftsbibliothek, 356, f. 184v \\ (Transcription)}

A definite decision about whether the hymn text "Conditor alme siderum" was sung in a rhythmic or non-rhythmic way from such a manuscript seems quite impossible, because the notation does not give us any informations in this respect. Nevertheless there are some scattered sources of the late Middle Ages which actually "declare themselves" with regard to rhythmic or non-rhythmic execution by distinguishing between short and long values. A specimen of this kind is provided by the St. Gall manuscript 529, shown in Example 2, which also dates from the $15^{\text {th }}$ century ${ }^{5}$ :

\section{Example 2 \\ "Conditor alme siderum" \\ St. Gall, Stiftsbibliothek, 529, p. 143 \\ (Transcription)}

So we can be sure now that by the $15^{\text {th }}$ century at the latest (and probably much earlier) there was at least the possibility of applying the sequence of short and long syllables in the metrical model to the musical execution. But then something unexpected happens: The means of rhythmic notation, which served in the St. Gall manuscript to fix in written form a rhythmic solution that is already perceptible in the verse structure and can easily be accomplished even without notation, open up a new choice for the
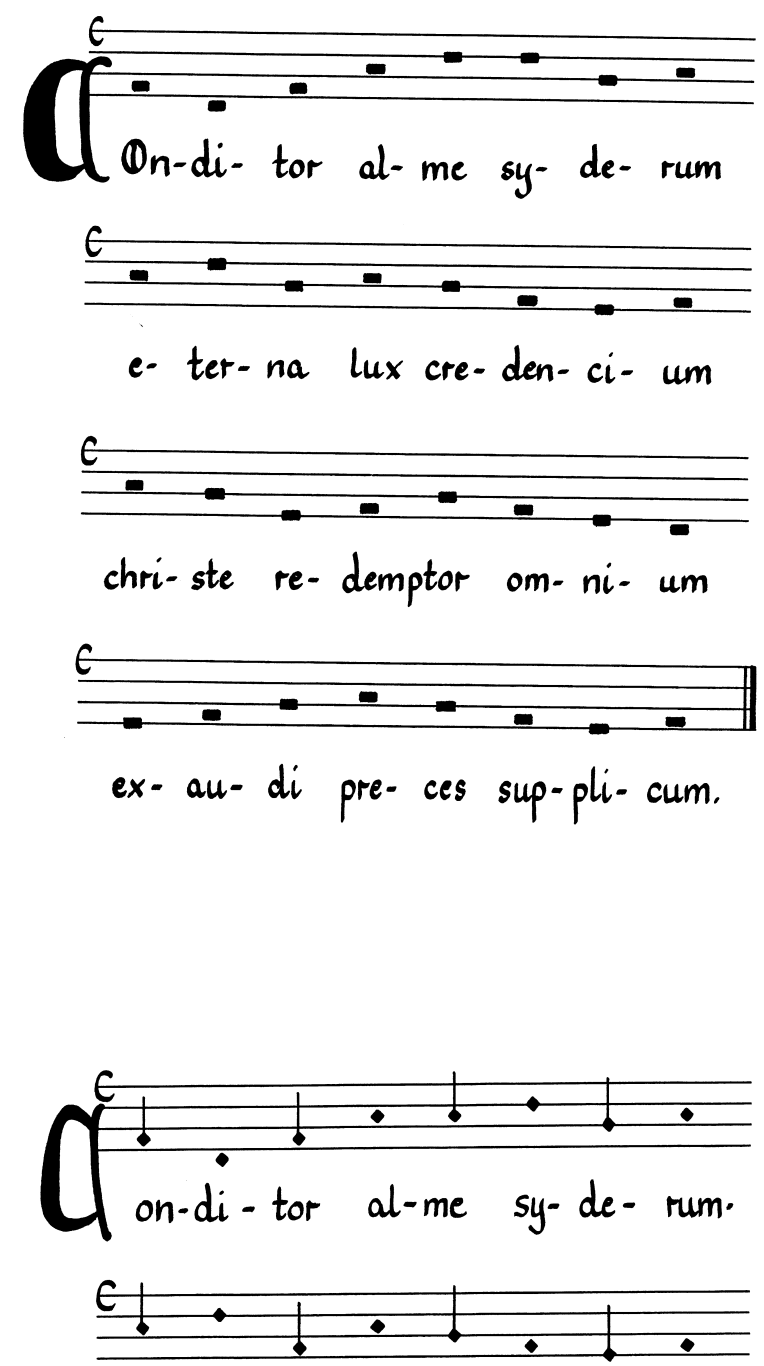
e- ter-na lux cre-den-ci-um.

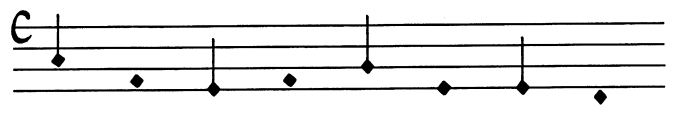
chri-ste re- demptor om-ni- um.

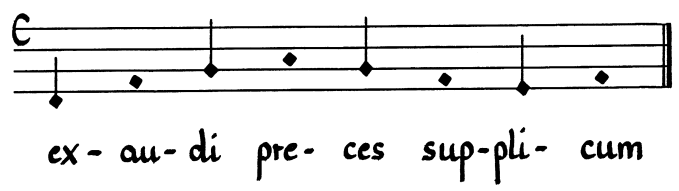

5. See Gustav Scherrer, Verzeichniss der Handschriften der Stiftsbibliothek von St. Gallen (Halle 1875), p. 162. 
musician, the choice of detaching the musical rhythm from that of the metrical model and, therefore, pursuing his own ways. On the other hand, if we ask why the musician should aim at a musical rhythm different from the metrical model, it becomes clear that even this decision is caused by the text itself.

The important fact we have to remember is that the short and long syllables, that is the quantities, are only one trait of the words, the prevailing trait as the classical poets and the poets in the classical tradition saw it. At the same time, though (we mentioned it before), the words have syllables which are stressed and others which are not, and in the post-classical times of modern languages, when Ancient Greek and Latin were no longer used as vernaculars, it is only this distinction between accents and non-accents that remains for the evaluation of a syllable.

For this reason there were in principle two different possibilities of handling an Ambrosian hymn text: Either one could consider the iambic verse model so important that one was willing to accept "wrong" word accents, i.e. accentuated syllables occurring on short positions of the model, or one had to leave behind the verse model in order to do justice especially to those word accents which are put wrongly in the model. As it seems, both possibilities were known in the course of history. The willingness to accept "wrong" word accents is already documented by our hymn text "Conditor alme siderum", therefore on the poetic level itself. Even if we cannot be sure how the first word was pronounced at the time when the text was written, whether people used to say "Cónditor" or whether the pronunciation was "Condítor" (indeed the word exists in this pronunciation, but with another meaning, in the German tongue today), we may take it for granted that the word "christe" at the beginning of verse 3 had its normal accent on the first syllable and that the stress on the second syllable which it gets when set at the beginning of an iambic dimeter was only accepted because the verse model was considered more important. Admittedly, it is possible that the procedure of our poet was caused by his firm belief that this second syllable had to be regarded as long syllable and that he only wanted to stick faithfully to the metrical principle; after all, the remaining syllables in the first stanza-apart from the first syllable of "preces" in verse 4 which he may have mistaken for a long one because of its accentare metrically correct (and the same goes for most syllables in the other stanzas). But in any case it is true that for the poet the verse model had to be realized above all and therefore was of overriding importance. And in this he was followed by our scribe in the monastery of St. Gall who provided the hymn text with short and long note values in continuous alternation.

Now, what about the second possibility of leaving behind the verse model in order to do justice especially to those word accents which are put wrongly in the model? I would like to take as an example another famous "Ambrosianus", the hymn text "Magnae deus potentiae". As we can see by a short glance at the first stanza, short and long syllables are placed here in strict observance of the metrical rules - a fact which makes it probable that this text was written some century before "Conditor alme siderum". So the poet restricts himself either to the use of iambic impulses, or (a licence which is explicitly conceded in the verse model of the "iambic dimeter") he substitutes the short quantity of the first or third iambus with a long one: 
Magnae deus potentiae

$--v---v-$

qui ex aquis ortum genus

partim remittis gurgiti

partim levas in aera

This sticking to the rules of the "iambic dimeter" would justify a musical realization of "Magnae deus potentiae" in which the syllables, as we have seen it in the St. Gall manuscript for "Conditor alme siderum", are pronounced in ternary time with a continuous repetition of the iambic foot short - long. Let us have a look at the non-rhythmic notation of the manuscript from Kremsmünster again, as it is shown in Example 3, and try this solution in ternary time with the melody written down there for the "Magnae deus potentiae" text ${ }^{6}$.

\section{Example 3 "Magnae deus potentiae" \\ Kremsmünster, Stiftsbibliothek, 356, f. 195 $^{\mathrm{v}}$ (Transcription)}

As a matter of fact, there is no obstacle which would prevent us from singing this melody in a series of iambic impulses, and so we should expect the hymn "Magnae deus potentiae", like "Conditor alme siderum", to show this short-longmodel in ternary time when being notated rhythmically. In this case, though, we are faced with a surprise: Indeed we find the hymn "Magnae deus potentiae" written down with rhythmic note symbols, even if the melody is a different one belonging to a long tradition of Spanish hymn melodies
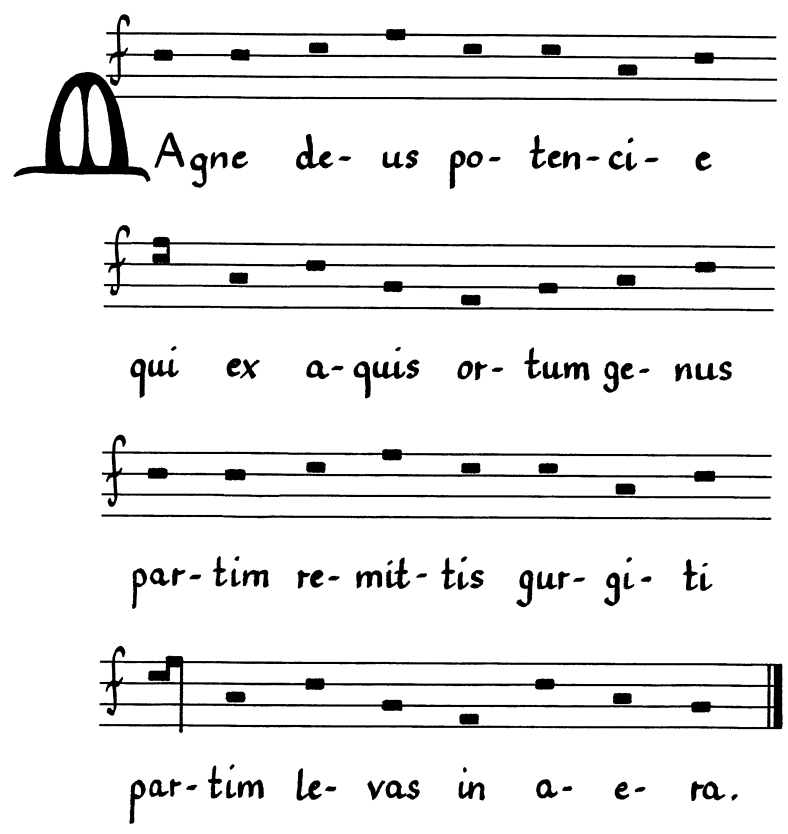

6. In the second copy (cf. note 4) the melody for "Magnae deus potentiae" is to be found on f. 196rf. - Also in this case both notations avail themselves of a four-lines staff, but the $f$-clef on the third line remains valid here without exception. At the beginning of verse 4 the particular form of the two-note ligature varying from verse 2 remains limited to the earlier manuscript. 
which can be traced back to the decades around 1500 and then covers a period of at least three centuries. The strange thing, however, is that in this tradition the relatively new means of rhythmic notation, which had been developed not until the $13^{\text {th }}$ century, is sometimes used for individual rhythmic solutions that cannot be understood -at least not only- by looking at the verse structure. What the Spanish musicians aim at instead in such cases may become more evident by having a closer look at the rhythmic melody for "Magnae deus potentiae", as shown in Example 47.

\section{Example 4 \\ "Magnae deus potentiae" \\ Ansó, Museo Etnológico, 76, f. 54 \\ (Transcription)}

I think, it is perceivable that the music does not adopt any ternary motion here, but that it develops in binary time: Two semibreves always make one brevis. Of course, even in binary time you can maintain the scheme of the iambic dimeter to a certain degree, if you want to. By using one single note value, for example that of the semibrevis, and putting the former lengths of the iambic model at the beginning of each bar the model is preserved in a way - only that the lengths are transformed into accentuated and the shorts into non-accentuated positions. A transformation of this kind actually takes place in verse 3 where the music starts with a sequence of five semibreves, before the semibreves are slowed down for the last three syllables to breves (a ritardando, so to speak, realized with the help of different note values).

In the remaining course of the melody, however, things are not as simple as that. Just by proceeding from verse 3 further on to verse 4 (which
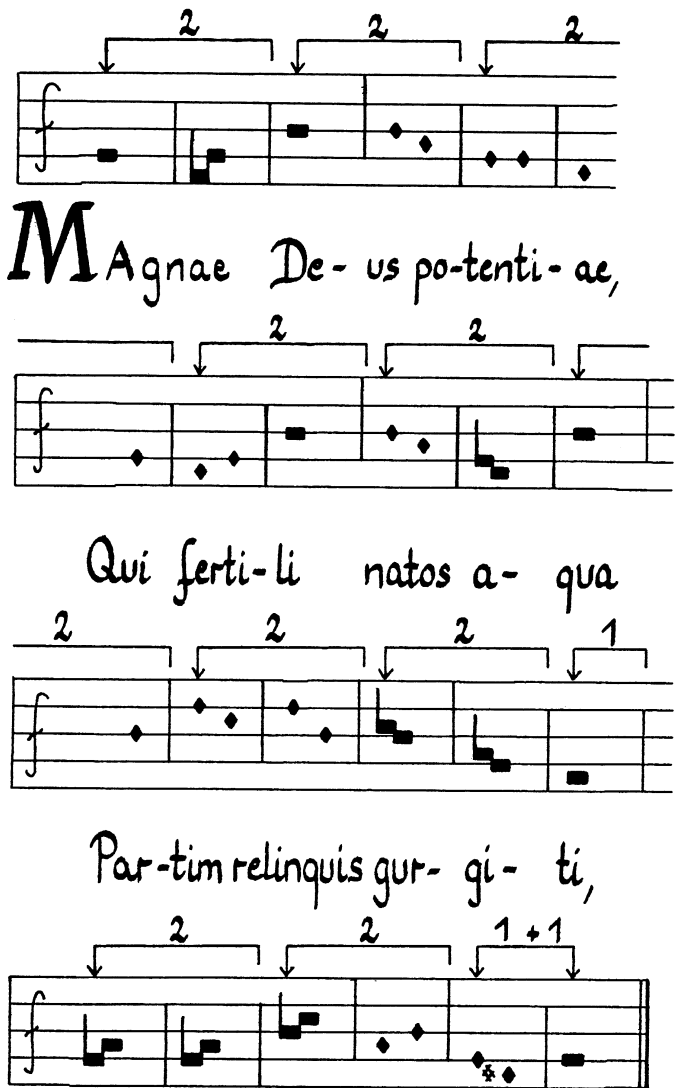

Par-tim le-vas in a-e-ra.

7. For a closer description of the source, which in all probability dates from the $18^{\text {th }}$ century, see my article "Zur Geschichte der Marienantiphon 'Salve regina'", Archiv für Musikwissenschaft, 46 (1989), pp. 257-270, here p. 265f. - The melody for "Magnae deus potentiae" was already published some years ago in my article "Rhythmische Hymnenmelodien", Kirchenmusikalisches Jahrbuch, 85 (2001), pp. 93-126, together with three other examples from the same manuscript: $f$ - $b$ flat- $b$ flat-b flat- $a-g-f-g-a-g-f$ ("Deus tuorum militum"), $f-g-g-a-b$ flat- $a-a-c^{l}-c^{l}-d^{l}-c^{l}-b$ flat- $a$ ("Custodes hominum psallimus angelos") and $d^{l}-g-d^{l}-e^{I}-c^{l}-b-c^{l}-c^{l}-b-a-g-a-b-g$ ("Sanctorum meritis inclyta gaudia"). 
suggests itself since both verses begin with the same word, "partim") we are faced with another situation. This becomes evident at first sight by the fact that verse 4 does not end with three breves, like verse 3 , but that the three breves have shifted to the beginning, and consequently the semibreves appear only afterwards. To be clear about this change: What is meant here, is not so much a "rhythmic crab", i.e. a retrograde motion realized on the rhythmic level. It is rather a diverse attitude towards the text which evidently has led the author to his decision, since by placing the three breves at the beginning the musical weight is brought to the first syllables of "partim" and "levas" where the accents of these words lie, instead of the second syllables which represent the long positions of the verse model. Only the last accent in this verse did not force the author to a similar decision: Here accent and long position of the verse model fall on the same syllable, the first one of "aera", and so the melody can return to the former semibreves, which put the long positions at the beginning of the bars, without problem.

Nevertheless, if we consider the declamation of verse 4 as a whole, there can be no doubt that the individual word accents now take priority over the regular verse model. This effort towards a musical realization of the word accents is also reflected in the pitch levels: So the initial $d$-e element for the first, accentuated syllable of "partim" is merely repeated for the second syllable, thereby laying stress upon the accent. After these two $d$-e elements which form a pair of bars the accentuation of the first syllable of "levas" in the next two bars turns out to be even stronger, since the pitch level is raised from $d$-e to $f$ - $g$ for the first syllable before sinking back to $e-f$ for the second one. In order to underline the accent at the beginning of the last word, "aera", the two final bars remain on the $d$ level again which is confirmed as keynote by replacing $e$, the tone above, with the leading tone $c$ sharp. Thus all word accents of verse 4 are supported by the constellation of the pitches, and we may finally add that in a similar way already the music of verse 3 had been anxious to stress the long positions of the verse model melodically, here by the use of relatively high pitches (the note $a$ on the second syllables of "partim" and "relinquis"

When looking at verse 4 we have to take into consideration, though, that its melodic outline as well as its rhythmic declamation are not entirely new, but follow the model given by verse 1: In both verses the melody starts on the $d$ level and reaches the upper third $f$ in bar 3 before returning to the $d$ level in bar 5, and in both verses the declamation has three long values at the beginning that give way to short values only from the fourth syllable onwards. This conspicuous rhythm is clearly caused by the specific distribution of accentuated and non-accentuated syllables in the initial phase of these verses which stands against the iambic nature of the verse structure since the accents lie on the first and third, and not on the second and fourth syllable. Therefore one could argue that in the passages concerned the short-long impulses of the iambus cede to their opposite, i.e. the long-short concept of the trochee, only that we have to deal now with accents and non-accents instead of lengths and shorts: "Magnae deūs" and "partīm levās" change into "Mágnae déus" and "pártim lévas".

8. See for this and other divergences from the original wording in Ansó, Museo Etnológico, 76 further below in the present article, pp. 14f., for the particular cases of "relinquis" (first stanza) and "éfferat" (fourth stanza) note 12. 
The rhythmic solution which fits so well verse 1 and 4 would prove disastrous, on the other hand, when applied to verse 2 , because in this verse -apart from the fact that its metrical organization again keeps strictly to the rules of the "iambic dimeter"- all accents lie on those verse positions that in the other two verses are not accentuated. Different to the trochaic-like "Mágnae déus" or "pártim lévas" the beginning of verse 2 has the main stress, in concordance with the verse model, on the second syllable, thereby gaining an iambic orientation even on the quality level: "qui fértili". Conversely, it is the second half of the verse now that gives the impression of a trochee being filled with two disyllables which lay stress on the first syllable: "nátos áqua".

The way in which the author reacts to this inversion of accents is no less simple than striking. Without changing the melodic progression of verse 1 (except for the last two notes) he just shifts it, by means of a short upbeat for the first syllable, inside the two-bar scheme, so that the former second bars take the initial position. At the same moment he ensures by continuing the accelerated declamation throughout the first half of the verse that not only the accent of "fertili", but also of "natos" can find its place at the beginning of a two-bar unit. Only for the last accent of verse 2 he had to content himself with a compromise in order to achieve a musically conclusive ending on the final note $f$ which the listener must accept as new tonal basis at this moment: Since there seemed to be no alternative to placing the final note at the beginning of a two-bar unit, he gave in and anticipated the accentuated first syllable of "aqua" into the former two-bar unit, at least providing it with a long value to make up for its weak position. Nevertheless, this is not enough to prevent the listener from grasping the final note, and the second syllable of "aqua" with it, as more important, and it may be anything but a coincidence that the word "aqua" preludes the only other passage in this melody where the iambic verse model clearly prevails over the accents, namely the word "partim" at the beginning of verse 3 .

If we look at how the Spanish melody for "Magnae deus potentiae" proceeds as a whole we can state, though, that it is not the lengths and shorts of the metrical system or of the words placed into it which are the focus of the author's attention. Instead of strictly observing the sacrosanct rules that go back to classical antiquity, he trusts more in his own feeling for language, i.e. an accent-oriented declamation which he himself would perceive as natural and therefore spontaneous. Because of these characteristics the melody for "Magnae deus potentiae" may be considered to be an exponent of a new trend that was of vital importance for the course of Music History since the $16^{\text {th }}$ century and that is marked by the effort of musicians to seize spoken language in its actual execution, as an important tool of human expression and communication related to the "here and now" of particular moments. So it is no longer the artificial creation of verses and stanzas which music has to realize above all, but the words and phrases as they are articulated during the normal speech act, in the form of prose.

Reflecting upon this new trend we should keep in mind that it was the same $16^{\text {th }}$ century which first began to appreciate the composer as "orator", a trained speaker who succeeds in reaching the minds and hearts of his audience by making use of all devices the rhetorical art has to offer, just as defined by Horace. Nor should we forget that, as a result of this concept, "modern composers" around 1600 were even ready to throw overboard the severe rules of composition taught by the Italian theorist Gioseffo Zarlino in order to produce every musical effect called for by the language without any 
impediment ${ }^{9}$. This is exactly the point of view held by Claudio Monteverdi against his critic Giovanni Maria Artusi, and it does not only put his madrigals on a new footing, but at the same time constitutes the basis for a new genre which in those years enters the stage of Music History and was to become, in a way, the epitome of European music, especially composed music, in more recent centuries: the opera $^{10}$.

We must not neglect to mention, on the other hand, that already decades before Monteverdi drew such far-reaching conclusions from Artusi's attack as to postulate a "seconda prattica", another way of composing different from Zarlino's theory, the call for a musical realization which takes the text seriously by making it intelligible for the listener as directly as possible was heard, and not only in the secular field (as we might assume after having mentioned madrigal and opera), but -very perceptiblyinside the Catholic church as well, who thereby reacted to criticism from the German Reformation. To avoid the text being covered up by too much music, composers were to limit themselves with regard to the means of elaboration that vocal polyphony disposed of in the $16^{\text {th }}$ century and seek simplicity instead.

The famous legend of the "salvation of church music" achieved by Palestrina, which, as it seems, originated as far back as in the later $16^{\text {th }}$ century $^{11}$, is connected to exactly this demand of the Catholic church for a sacred music that supports the intelligibility of the text and therefore can be used for liturgical purposes: As the legend says, Palestrina, by presenting his Missa Papae Marcelli to the highest Roman dignitaries, was able to avert an imminent ban on polyphonic settings in the divine service,

9. In the argument between Zarlino's pupil Artusi and Monteverdi about the right way of composition, which is mentioned in the following, the category of the "modern composer" plays an important role. Artusi himself describes the contents of his treatise L'Artusi Overo Delle imperfettioni della moderna musica (Venice 1600) in its subtitle as "two discussions in which many useful and necessary things for the modern composers are treated". The preliminary remark to Monteverdi's Quinto Libro de Madrigali (Venice 1605) repudiates Artusi's attack with the assurance that "the modern composer builds on the foundations of truth". That these words refer to the musical treatment of the text is made clear by the explanations to the preliminary remark given in Monteverdi's Scherzi musicali (Venice 1607) by his brother Giulio Cesare. Here Artusi is blamed for not taking into consideration the "oration" which is omitted "in such a way as if it had nothing to do with the music". A few years later Adriano Banchieri in his Cartella musicale nel canto figurato fermo e contrappunto (Venice 1614) defines the "modern composer" more in the sense of the two Monteverdis stating that "he tries to imitate a perfect orator who wants to unfold a learned and well-interpreted oration".

10. It seems to be no coincidence that opinions similar to Monteverdi's view are again expressed by operatic composers exactly at the time when the "preoccupation of music with language", according to Georgiades, approaches its historical destination in the works of Beethoven (regardless of the fact that each of these positions, apart from the very fundamental aspect we are dealing with, has to be differentiated from the others, when it comes to a more detailed examination). In 1769, for instance, Gluck states in his preface to the printed score of Alceste: "There is no rule of order which I have not believed necessary to be eagerly sacrificed for the effect." A comparable attitude can be perceived in the famous letter Mozart wrote about opera in October 1781, when he claims that "we composers" would produce "unsuitable music", if "we faithfully followed our rules (which in the old days when people did not know better were all right)". But as he underlines simultaneously that the same goes for librettists it becomes evident that the greater independence from the rules in favour of the actual task which may include not least the connection with other art forms, as postulated for composition since 1600, presents only one facet of a new interpretation of art as a whole (and thus establishes a new image of the artist that constitutes the basis for the idea of the "genius" in the $18^{\text {th }}-20^{\text {th }}$ centuries). In the final consequence the skilful handling of generally accepted rules as criterion for the judgement of artefacts can now be replaced by each work of art fending for itself. This means that the specific, unique features of the work must be evaluated anew in every single case, thoroughly scrutinizing its individual conditions and the conclusions which the artist has drawn from them, in order to weigh its artistic rank. At the same time Western art production sets foot on a path that leads to a deliberate dissolving of everything anchored in convention and therefore to the deep crisis breaking out shortly after 1900. With its radical jettisoning of the traditional, the situation of the avant-garde in the $20^{\text {th }}$ century is marked then by a loss of validity, substituted by feverish experiment in which inheres the danger of arbitrariness.

11. See Franz Körndle, "Was wusste Hoffmann? Neues zur altbekannten Geschichte von der Rettung der Kirchenmusik auf dem Konzil zu Trient”, Kirchenmusikalisches Jahrbuch, 83 (1999), pp. 65-90, especially pp. 74-76 (section IV). 
because in this composition, thanks to a mostly plain, homophonic declamation, the words of the "Ordinarium missae" can be understood easily at every moment.

How serious the Catholic church was about its demand, is clearly indicated by the fact that even the long passages on a single vowel, the so-called "melismata", which from time immemorial belonged to the characteristic features of certain genres of Gregorian chant, came under fire now, since these melismata prolonged the rendering of the text to such an extent that its context could not be grasped any more by the listener, or at least only with great difficulty. Indeed, at the beginning of the $17^{\text {th }}$ century the chants concerned were published in revised versions in which the melismata had been almost completely weeded out, and in this mutilated state they were generally sung until the early $20^{\text {th }}$ century.

All the same, there is quite another way of approaching language through music during the $16^{\text {th }}$ century. Beyond the common endeavour to go back to classical culture (an endeavour which demonstrably had also a strong impact on the idea of converting the speech act, as a means of human expression, into music as directly as possible), it was the preoccupation with the ancient languages Greek and Latin in particular that, with humanism, regained unexpected relevance, and not the least of its consequences was the return to the metrical rules of classical poetry.

Again we must lay stress on the fact, though, that humanism was by no means an exclusively secular-oriented movement, even if its main current had taken this course from the beginning. Throughout the $16^{\text {th }}$ century there were also voices inside the Catholic church which one may call "humanistic voices". And here, as expected, the old song genre of the Gregorian repertory that, with its poetic structures and, above all, the application of the metric principle (that is of lengths and shorts), has its roots as far back as late antiquity -I am talking about the hymn, of course- becomes the focus of new attention.

But despite their sympathy for the hymn, due especially to its application of the metric principle, humanists belonging to ecclesiastical circles took the newly acquired knowledge about the laws of prosody so seriously that they became indignant at the real or supposed errors with regard to the use of quantities in those metrically built poems - errors which they considered a symptom of their late, postclassical period of origin in the Dark Ages of medieval times and therefore long after the golden age of Antiquity. For this reason they loudly asked for an emendation of the passages concerned, if not a complete abandonment of all hymn texts which, according to the laws of prosody, had to be rated as "non-impeccable". These reformatory efforts reached their final goal in 1629 when Pope Urban VIII, in preparing a new edition of the Roman breviary, installed a commission of four Jesuits with the object of revising all hymn texts to be found in the breviary. Thus a total of 95 hymn texts was examined and, as the commission itself stated, 952 irregularities were corrected. In the same year the revised form of the texts was published separately, i.e. apart from the breviary, in a Roman edition entitled Hymni Breviarii Romani.

Checking in this edition, for instance, the three places in the first stanza of "Conditor alme siderum" that we ourselves have judged as problematic, namely the initial word "Conditor" in verse 1, the initial word "christe" in verse 3 and the word "preces" in verse 4, we can see that it is indeed these places which have been changed. Let us glance for a moment at the two versions, the traditional and the revised one, in order to compare them: 
Kremsmünster, Stiftsbibliothek, 356, f. $184^{\mathrm{v}}$

Conditor alme syderum

eterna lux credentium

christe redemptor omnium

exaudi preces supplicum
Hymni Breviarii Romani, f. $28^{\mathrm{r}}$

Creator alme siderum,

Aeterna lux credentium,

IESU Redemptor omnium,

Intende votis supplicum.

At times, though, it seems as if the reformers overstepped the mark, claiming errors where even at the height of classical Latin poetry no-one would have seen any reason for objection. So the sequence of two different syllables with their vowels directly encountering, a so-called "hiatus", in verse 2 of "Magnae deus potentiae" apparently incurred the displeasure of the commission regardless of the fact that a hiatus whose first element is formed by a monosyllable at the beginning of an iambic verse, as in this case, was taken as correct by ancient poets. Nevertheless verse 2 of "Magnae deus potentiae" also obtained a new shape changing from "qui ex aquis ortum genus" into "Qui fertili natos aqua"12.

Owing to the fact that the main current of humanism, as mentioned, was turned towards the secular sphere, the concern of humanists for the metrical rules of classical poetry led in the musical field, above all, to the composition of Latin texts from Roman times. Here the Odes of Horace play an important role: Already at the beginning of the $16^{\text {th }}$ century they were set to music, strictly observing lengths and shorts, in a simple way, designed to serve a metrically correct declamation, by Petrus Tritonius, a disciple of the German humanist Conrad Celtis, in the following period also by other composers, among them Ludwig Senfl, who was employed at the Ducal court at Munich.

It did not take much time, though, before a kind of hymn setting which relied on the long and short syllables of the text, thereby fitting in with humanistic ideas, made its appearance in musical sources as well, partly set by the same composers who occupied themselves with classical Latin poems, like Ludwig Senfl. In this context we meet with the "Ambrosianus" and its "iambic dimeter" again, for which a realization in ternary motion seems so suitable - we already have looked at a typical example of this older tradition in the St. Gall manuscript 529. Nevertheless the composer might react now to a very common practice in Ambrosian hymn texts, namely the substitution of the first and third short syllable of the metrical model with a long one (we mentioned it before), by applying long note values also to these places of the verse. So his seriousness in observing the actual lengths and shorts of the text went so far that he was even willing to abandon the continuous flow of the ternary motion.

On the other hand, when looking at hymn settings of the $16^{\text {th }}$ century, we encounter metrical models which, like the "Ambrosianus", are present throughout the history of the hymn, but which do not as easily permit a consistent measurement of time, be it in ternary or in binary units. The settings show that composers in such cases again and again conceded a well-aimed manipulation of certain syllables, that is a change of their quantity, for the musical rendering in order to save the metrical model on the

12. In addition, the manuscript from Ansó replaces the word "remittis" in verse 3 by "relinquis". Another alteration which goes beyond the Roman revision of 1629 is contained in the fourth stanza with verse 2 using "éfferat" instead of "levet". The new syllable occurring here can be incorporated into the verse scheme by eliding the final syllable of the precedent word "Nullum", as it was common in the case of words ending with " $m$ " and a few other cases in late Roman poetry. 
whole. Of course, one could ask whether the consistent measurement of time which is gained hereby in dealing with these metrical models was a new approach to the problem by hymn composers of the $16^{\text {th }}$ century, or whether it belongs to an older tradition, similar to the ternary motion for the "Ambrosianus". We will return to the question as soon as we are facing our next musical example from Spain.

But no matter what the right answer to this question may be all data collected so far on the musical rhythmization of hymn texts in the $16^{\text {th }}$ century prove a strong metrical tendency at work which is fully in line with the erudite humanistic view of that time, but which is equally opposed, on principle, to a spontaneous, unpretentious consideration of the stressed syllables by the musician according to his own feeling for the language, which dominates the rhythmic melody for "Magnae deus potentiae". This metrical tendency becomes noticeable very strongly even in our Spanish repertory, and we cannot exclude the possibility that in the melodies concerned an erudite humanistic influence is making itself felt.

However, before we turn to our next example to illustrate this presence of the metrical tendency in the Spanish hymn melodies, we must reflect for a moment upon what relevance the two different approaches to language, including its musicalization, which can be clearly distinguished in the $16^{\text {th }}$ century, actually have for the rendering of the text "Magnae deus potentiae" with its Spanish melody, since at a closer look it becomes evident that we have not only to deal with the tendency towards the natural word accents here. Certainly it is true that the music turns away from the observance of long and short positions in the verse model to emphasize the word accents, even if the observance of long and short positions, as traditional procedure of handling the "Ambrosianus", still is discernible, particularly in the transition from verse 2 to 3 . On the other hand we should note that the text, at least in our manuscript, makes use of the revised wording contained in the Hymni Breviarii Romani of 1629 (with additional changes in the first and fourth stanza) - a wording which aims at an even greater correctness in the application of the metrical laws than the original version ${ }^{13}$. In adjusting the music to the natural word accents, but at the same time referring to a new wording of the text which is extremely anxious to observe the right position of lengths and shorts in the verse, the notation of "Magnae deus potentiae" is a living testimony to the divergence of the two different approaches to language we have identified. In this manner it reflects an historical field of tension in which one approach as well as the other is possible.

And yet the relations of text and music with the language in Spanish hymn melodies do not necessarily differ to such an extent as in this case. Indeed there is a way for the musician to combine an orientation towards the verse model throughout the entire melody, as would be the obvious thing to do in view of the humanistic text revisions, with his desire to emphasize the word accents in a, so to speak,

13. If one considers the emphasis which at the beginning of verse 2 is laid upon the second note $c$ (a note which was entirely unstressed at the beginning of the melodically identical verse 1), it would appear that the melody was actually designed on the basis of the revised wording, because only there does the second syllable of verse 2 which falls on this note have a strong accent ("Qui fértili"), whereas the original text version, on the contrary, accentuates the first and -even more- the third syllable again, as in verse 1 ("quí ex áquis"). Assuming that the Roman commission did not take over the new formulation which gives particular weight to the second syllable from an older humanistic version, and that there was no other version which underlined the second syllable to a similar degree before, one could conclude that the melody came into existence not earlier than in the year 1629. 
well-balanced compromise. This is exactly what happens in a group of melodies which no longer restrict themselves to putting down in written notation the popular triple meter of the "Ambrosianus" (thus we find even in Spain, as in the manuscript from St. Gall, the famous hymn melody for "Conditor alme siderum" in ternary motion), but which, in accordance with the humanistic current inside the Catholic church, also take up the more learned, demanding types of hymn stanzas that we have already mentioned in connection with German hymn settings, for instance by Ludwig Senfl, and convert them into a regular ternary or binary rhythm although their metrical scheme, as we said, does not allow by itself such a regular measurement of time. So we are faced with an interesting musical procedure again for which any documentary evidence from earlier centuries is lacking.

How this procedure manages, while fundamentally observing the metrical scheme, not only to create a regular measurement of time, but also to put the word accents in the right places, becomes evident when we take a look at our next melody, applied to the hymn text "Claudium quisquis colis aemulare", in Example 5. The text belongs to a particularly widespread of these more learned, demanding types of hymn stanzas, the "sapphic stanza", which consists of three long verses, each of them subdivided into two halves, and a short verse, modelled after the metrical scheme of the first half. So the whole stanza shows the following distribution of lengths and shorts ${ }^{14}$ :

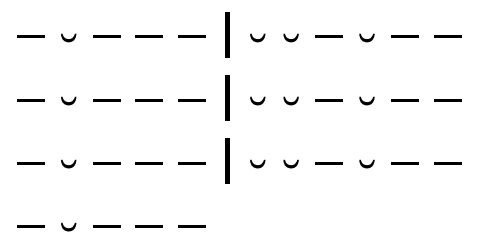

It can be easily seen that any musician who wants to adopt the metrical scheme of the "sapphic stanza" as musical rhythm is confronted with serious problems. As far as the shorts are concerned, there are two places in the course of the long verse -one in the first and one in the second half- where a single short appears, whereas at the beginning of the second half we find two shorts in succession. If only because of these circumstances, a solution in constant ternary or binary time is hardly realizable. Theoretically one could think of some more intricate rhythm, of course, but always on condition that the value of the lengths has to remain flexible. On the other hand, this would mean to disregard the prosodic law which says that every length must invariably comprise the duration of two shorts.

As the melody for the text "Claudium quisquis colis aemulare" demonstrates (and it may be considered a typical exponent of the musicalization of the "sapphic stanza"), it was not this path musicians took. They preferred to modify the "sapphic stanza" itself, i.e. its distribution of lengths and shorts, in a slight way and then to adopt this new rhythmic sequence with its regular measurement of time direct-

14. In accordance with the general practice of metrical poetry all final syllables are given as lengths, regardless whether the final position is actually held by a long or short syllable. 
ly for the musical rendering. Actually, the substitution of two lengths with shorts was sufficient to change the inner structure of each long verse (and accordingly of the short verse as well) from an irregular constellation of lengths and shorts into a binary procession-like rhythm. Let us see how this manipulation works in detail:

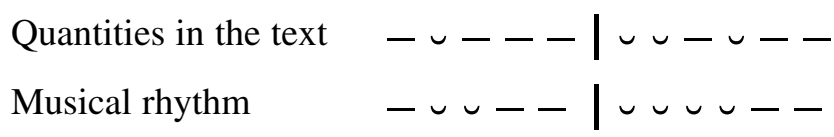

This new rhythmic pattern suggests itself all the more since it places the emphasis on the same positions which obviously were regarded also by the hymn poets as particularly important and therefore as a rule provided with word accents. For that reason we must even ask whether the hymn poets themselves had already drawn the conclusion from the inability of the "sapphic stanza" to establish a regular measurement that they should, by this calculated placing of the primary stresses, lay another scheme over the metrical framework in order to shift the perception of the "sapphic stanza" towards such a regularity.

In any case, through the order of the accents as well as through the musical rhythm, at the performance of the "sapphic stanza" it is usually the following verse positions which stand out: in the first half of the verse the initial syllable and the penultimate, which since medieval times has also played a significant role in the poetic practice and theory of accentuating verse, and in the second half, apart from another stress on the penultimate (now the actual penultimate of the whole verse), again the initial syllable. Even if it is true that this syllable remains short, as on the metrical level, it nevertheless accumulates some weight for two reasons: to start with, because it takes the initial position of the second half and therefore can be perceived as analogous to the initial position of the first half which has a long syllable, and moreover, because this analogy is confirmed by the same duration of both halves (four lengths or eight shorts) and their similar structure.

Thus the Spanish musician who invented the melody for "Claudium quisquis colis aemulare"15 had already a prefabricated rhythmic concept at his disposal, and the only task left for him was to fill

15. With other hymn texts also using the "sapphic stanza" the melody is to be found in several Spanish editions of the $18^{\text {th }}$ century, for instance with the text "Iam redit laeto rutilans Olimpo" in the Manual procesional para el uso de los religiosos del orden de N. P. S. Juan de Dios (Madrid 1788), p. 93f., and with the texts "Petre qui iussu genitricis almae" and "Voce concordi soboles beati" in the Manual de bendiciones, oficios, procesiones, y Semana Santa con el oficio de sepultura, Arreglado todo á los Decretos de la Sagrada Congregacion de Ritos, para el uso de los Religiosos Descalzos de nuestra Señora de la Merced (Madrid 1789), pp. 174-177 resp. pp. 177-180. In the Rituale sacri, ac regalis ordinis Beatce Virginis Marice de Mercede (Madrid 1770), where the melody reappears with the text "Petre qui iussu genitricis almae" on pp. 329-332, the same text is given afterwards, on pp. 332-335, a second time with another melody which on the one hand shows a close relationship with the melody $a-e-g-f-e-c-f-$ $e-c-d-c$ for "Virginis laudes canimus pudice", listed in note 16, but which proceeds, in contrast to the melodies for the "sapphic stanza" mentioned so far, in ternary and not in binary meter. A certain resemblance to the melody for "Claudium quisquis colis aemulare" can be observed in the melody $f-g-a-b$ flat $-c^{l}-a-c^{l}-b$ flat- $a-f-g-g-f$ for "Gaude propago candida" in the same edition on pp. 450-452, which realizes a binary motion with some long-short-short-long elements in the way of "sapphic melodies", although the text belongs to the "Ambrosian" category. 
it with a sequence of notes capable of supporting its constellation of accentuated and non-accentuated positions. Without more ado he accomplishes this task by providing a single melodic line which is introduced together with verse 1 to be transposed afterwards, for verse 2-3, up a fifth and a third before returning in verse 4 to the original pitches, even if somewhat shortened since verse 4 is only half as long as the verses preceding. This return to the lower level where it had started determines not only its conception as a whole, however, but also, to the same extent, the direction it takes inside each verse. Let us have a look at verse 1 to study the concrete course of the melody in detail: Beginning on $f$ it moves on to the upper third $a$ at the end of the first half, stressing the penultimate by an even higher pitch, the upper second $b$ flat of the arrival note. After the caesura in the middle of the verse it starts with the same weight on $b$ flat, thereby stressing the first syllable of the second half now, before descending to the initial pitch $f$ again. Interestingly enough, the stress on the first syllable of the second half is underlined also rhythmically by prolonging it with a dot, regardless of the fact that on the metrical level as well as in the rhythmic concept the melody is based on this syllable is short ${ }^{16}$.

\section{Example 5 \\ "Claudium quisquis colis aemulare" Ansó, Museo Etnológico, 76, f. 124 (Transcription)}

Comparing the melody for "Claudium quisquis colis aemulare" with the melody for "Magnae deus potentiae" one could argue that we are faced here with two different attempts of music to occupy itself with language, both of which seek a unity that as an ideal state lost since the times of antiquity belongs to the historical memory of Western culture. To understand this, we

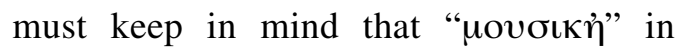
ancient Greece saw no reason at all for separating music and language, so that the
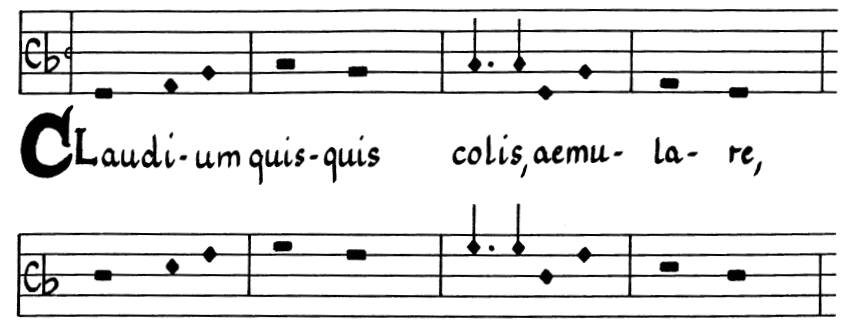

$$
V_{i} \text { - citae-ta-tem meri-tis,pu-er-que }
$$

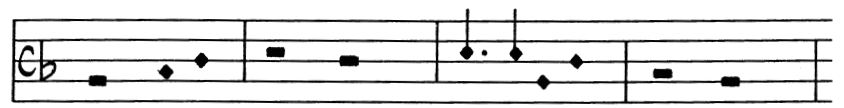

Jam se-nex di-ci po-tuit,pa- ren-tum

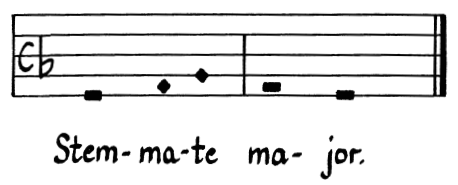

16. The same rhythm as in "Claudium quisquis colis aemulare", including the dotted note in the second half of the long verses, is used by many other Spanish melodies for the "sapphic stanza". As examples we may quote: $d^{l}-c^{l}-c^{l}-d^{l}-a-f-g-a-f-e-d$ in the Rituale fratrum excalceatorum, ordinis eremitarum S. P. N. Augustini, congregationis Hispaniae, et Indiarum (Madrid 1735) with the texts "Te canunt omnes Nicolae gentes" on p. 205f. and "Incola abruptae rigidus cavernae" on p. $435 ; c^{l}-b-a-c^{l}-g-a-g-f-$ a-g-c in the Explicacion de la teorica y practica del canto-llano y figurado, ordenada Por el P. Fr. Nicolas Pasqual Roig, Organista en el Real Convento de N. G. P. S. Agustin de la Ciudad de Valencia para uso del noviciado (Madrid 1778) with the text "Iste confessor domini colentes" on p. 137f. (here also the sequence of notes in the short verse is identical with "Claudium quisquis colis aemulare", only that it is transposed up a fifth in order to allow the melody to reach the initial pitch $c^{l}$ again at the end); $f$ - $a-b$ flat$c^{I}-f-b$ flat-a-g-f-c-f in the Ritual carmelitano de los Religiosos, y Religiosas de la orden de descalzs. de $n^{a}$. madre ss ${ }^{a}$. la virgen Maria del monte carmelo, de la primitiva observancia, en esta congregacion de España, è Indias. Parte segunda: Procesionario 
measurement of time carried out by music and language coincided quite naturally, at least where the audible realization of poetry was concerned ${ }^{17}$. On the other hand, it seems obvious that instrumental practice had its own roots even then - roots to which the reflective mind penetrated much less, though. And yet we must finally extend our considerations to instrumental practice in order to get a well-balanced picture of the relation between music and language in Western culture as well as the consequences this relation had for the further development of European music.

But before doing so, we should recapitulate briefly the main features which characterize the two tendencies we have found in our rhythmic hymn melodies from Spain. Let us begin with "Claudium quisquis colis aemulare", because it seems to be in some respect the easier case compared to "Magnae deus potentiae". What "Claudium quisquis colis aemulare" aims at is a congruence of the musical rhythm with the metrical model. The transformation of two lengths into shorts effected by the music indicates, however, that the ancient unity of rhythm on the musical and on the language level can no longer be taken for granted. Musical rhythm faces the lengths and shorts which appear within the framework of specific verse structures as a force in its own right, and this is even true if the poets, according to the speculation above, had already created, with the help of word accents, an additional level of measuring the time in order to establish regular intervals, because this striving for regular intervals is, strictly speaking, a musical one which has nothing to do with the old unity of music and lan-

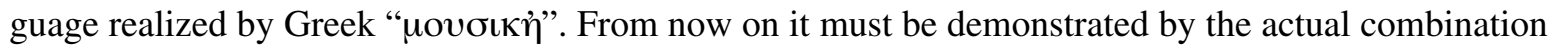
of both elements, the musical and the textual, by "experiment", we could say, whether and, if so, in which way it is possible to synchronize them again.

Of course, even "Magnae deus potentiae" aims at a congruence of musical and textual rhythm, but here the author of the melody, as far as textual rhythm is concerned, refers particularly to the word accents right from the beginning; they are the point from which he tries to grasp the dimension of textual rhythm. Since the word accents, much more than the lengths and shorts of the metrical verse scheme, occur at irregular distances that no longer reveal any systematic order, the autonomous force of musical rhythm is called for still more urgently than in the case of "Claudium quisquis colis aemulare", however. Without a doubt it is a question of adjusting the irregularity of the accents on the musical level now, that is, to bring them into regular intervals - a task which can be only fulfilled through a varying pace of declamation. In this sense the measurement of time in "Magnae deus potentiae", as

\footnotetext{
$y$ funeral (Madrid 1789) with the text "Coelitum Joseph decus atque nostrae" on pp. 147-149; $f-f-f-g-c-g-a-b$ flat- $a-a-g-f$ in the

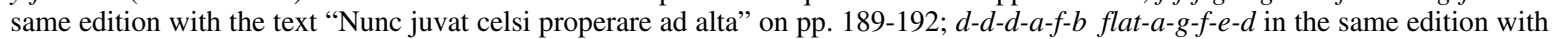
the text "Regis aeterni generose miles" on pp. 213-216; $f-f-g-a-f-a-g-a-b$ flat-c ${ }^{l}-f$ in the Rituale sacri, ac regalis ordinis Beata Virginis Maria de Mercede (Madrid 1770) with the text "Voce concordi soboles beati" on pp. 336-338; $c^{l}-b$ flat- $a-c^{l}-b$ flat- $a-b$ flat-a-g-a-f-g-f in the same edition with the texts "Virginis proles opifexque matris" and "Urbis aeternae celebres triumphos" on p. 398f. resp. pp. 479-481 (with the dotted note only in the first and second verse). Furthermore, I would like to draw attention to the melody $a-e-g-f-e-c-f-e-c-d-c$ in the same edition with the text "Virginis laudes canimus pudicae" on pp. 216-218, since here, apart from the usual dotted note in the second half of verse 1-3, even the second note in the first half and, correspondingly, in verse 4 is always dotted; the melody is also contained in the Rituale sacri, et regalis ordinis B. V. Maria de Mercede (Sevilla 1701), again with the text "Virginis laudes canimus pudicae", on p. 260f.

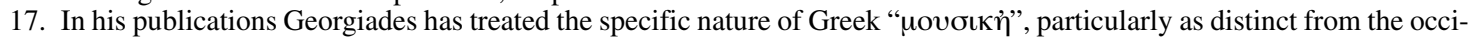
dental duality of music and language, several times, above all in Der griechische Rhythmus: Musik - Reigen - Vers und Sprache (Hamburg 1949) and in Greek Music, Verse and Dance, Merlin Music Books, 5 (New York n.d.) resp. its revised German version Musik und Rhythmus bei den Griechen: Zum Ursprung der abendländischen Musik, rowohlts deutsche enzyklopädie, 61 (Hamburg 1958).
} 
the melody makes quite evident from the beginning, is directed towards regularity, whereas its concrete filling becomes deliberately irregular: At times there are more syllables, at times there are less.

But with regard to the measurement of time it is not only the aim towards regularity which in "Magnae deus potentiae" seems noteworthy. Let us think back again to an especially striking moment, the transition from verse 3 to verse 4 . Here the melody returns to the initial principle of time filling which had always placed the word accents at the beginning of new time units and had been lost in the transition from verse 2 to verse 3 , since the time units then offered themselves to a declamation according to the metrical model. What strikes the listener in the transition from verse 3 to verse 4 now, is a sudden jerk which runs through the measurement of time: While earlier on the time units had consisted, since the beginning, in groups of two bars which the listener had been able to settle in quite comfortably, the end of verse 3 confronts him with a single bar. Through this bar the previous measurement of time in regular groups of two bars is severely shaken, before the regular groups of two bars are reinstalled for the rest of the melody.

So, when looking at "Magnae deus potentiae" as a whole we can observe how music, by its "preoccupation with language", goes through a learning process, how it develops, in its encounter with language and the task to cope with this encounter, new possibilities, and we may add that it is a learning process which was of crucial importance for the evolution of European music. This becomes even clearer as soon as we trace music "per se", instrumental music, that is, which can do perfectly without language, through the last centuries of Music History. The first sources that transmit instrumental music in an unambiguous and valid form to us were written in the $15^{\text {th }}$ century, and they contain examples of organ playing which proceeds as a continuum of rhythmically homogeneous formulae. We are facing a music beyond language - in other words: a music which has never got into contact with language. It is the same purely musical approach that still sets the tone of Bach's music. Simultaneously, though, instrumentalists in the $15^{\text {th }}$ century began to orient themselves toward vocal settings which are tied to language. This opens a new development which also enables instrumental playing more and more to assimilate the attitude of spoken language, implying that it leaves its continuum to produce "discontinuity", to shape a given moment as unique, and to do so, in the first place, by rhythmic means. Here the approach of instrumental music becomes an entirely different one, and it marks, at a highly advanced stage of Music History, the great instrumental music of the Viennese Classics. Thrasybulos Georgiades, whose ideas about the relation of music and language in European culture served as a starting point for our own reflections, has demonstrated this characteristic trait of Viennese Classical music repeatedly in his own, impressive way ${ }^{18}$.

As the rhythmic hymn melodies from Spain that we have chosen as examples attest, this growth of occidental music is a process of considerable complexity which evolves in many ramifications and individualizations. Thus for the musicologist who wants to grasp the history of music in its entirety and to understand all its implications it seems methodically essential not only to stand still marvelling at a

18. See for instance his articles "Aus der Musiksprache des Mozart-Theaters”, Mozart-Jahrbuch 1950 (Salzburg 1951), pp. 76-98; "Zur Musiksprache der Wiener Klassiker”, Mozart-Jahrbuch 1951 (Salzburg 1953), pp. 50-59; "Mozart und das Theater", Mozart, seine Welt und seine Wirkung (Augsburg 1956), pp. 103-120 (all of them republished in: Thrasybulos G. Georgiades, Kleine Schriften, Münchner Veröffentlichungen zur Musikgeschichte, 26 [Tutzing 1977]). 
few high points, but to become acquainted with those long-lived traditions by which the great and unique was prepared and on which it is founded. In this sense a melody like "Magnae deus potentiae", even if hidden under the surface of more familiar manifestations of Music History, draws our attention to fundamental techniques in the musical treatment of language which were to be decisive for the further development of Western composition, and, with singular clearness, it shows these techniques to be the result of a confrontation between independent musical pervasion of time and metrical or rhythmic procedures on the language level. By studying "Magnae deus potentiae" we therefore get a valuable insight which would be denied if considering only well-established vocal setting and the impact it had on instrumental music. That is the reason why we, as musicologists, are obliged to pay attention also to the less known forms of music which at first sight may look insignificant, because only in this way we will finally obtain a complete appreciation of the forces that led to the rise of the fascinating phenomenon called "Music History". 